ARTICLE

https://doi.org/10.1038/s41467-019-09258-y

OPEN

\title{
Meta-analysis shows positive effects of plant diversity on microbial biomass and respiration
}

\author{
Chen Chen ${ }^{1}$, Han Y.H. Chen (1) ${ }^{1,2}$, Xinli Chen ${ }^{1}$ \& Zhiqun Huang (1) 2,3
}

Soil microorganisms are key to biological diversity and many ecosystem processes in terrestrial ecosystems. Despite the current alarming loss of plant diversity, it is unclear how plant species diversity affects soil microorganisms. By conducting a global meta-analysis with paired observations of plant mixtures and monocultures from 106 studies, we show that microbial biomass, bacterial biomass, fungal biomass, fungi:bacteria ratio, and microbial respiration increase, while Gram-positive to Gram-negative bacteria ratio decrease in response to plant mixtures. The increases in microbial biomass and respiration are more pronounced in older and more diverse mixtures. The effects of plant mixtures on all microbial attributes are consistent across ecosystem types including natural forests, planted forests, planted grasslands, croplands, and planted containers. Our study underlines strong relationships between plant diversity and soil microorganisms across global terrestrial ecosystems and suggests the importance of plant diversity in maintaining belowground ecosystem functioning.

\footnotetext{
${ }^{1}$ Faculty of Natural Resources Management, Lakehead University, 955 Oliver Road, Thunder Bay, Ontario P7B 5E1, Canada. ${ }^{2}$ Key Laboratory for Humid Subtropical Eco-geographical Processes of the Ministry of Education, Fujian Normal University, Fuzhou 350007, China. ${ }^{3}$ Institute of Geography, Fujian Normal University, Fuzhou 350007, China. Correspondence and requests for materials should be addressed to H.Y.H.C. (email: hchen1@lakeheadu.ca) or to Z.H. (email: zhiqunhuang@fjnu.edu.cn)
} 
S oil microorganisms make up a significant portion of biodiversity and play a critical role in many ecological processes, such as the cycling of carbon and nutrients ${ }^{1-4}$. Plant species diversity continues to decline due to anthropologically initiated environmental degradation ${ }^{5}$, and the decrease in plant species diversity has been recognized as a major threat to ecosystem functions and services ${ }^{6,7}$. Despite the critical influence of plant diversity on plant resources available for soil microorganisms and alterations to the micro-environment ${ }^{8-13}$, the global effect of reduced plant diversity on soil microbial abundance, fungi:bacteria ratio, Gram-positive $(\mathrm{G}+)$ to Gram-negative $(\mathrm{G}-)$ bacteria ratio and function remains uncertain.

Plant diversity is an important factor for microbial biomass, fungi:bacteria ratio and $\mathrm{G}+: \mathrm{G}-$ bacteria ratio. Soil microbial biomass can increase with plant diversity due to a greater amount of carbon and nutrient resources available for soil microorganisms from increased aboveground litterfall and belowground fine root mortality in species-rich plant communities ${ }^{14-19}$. Also, mixing functionally different grassland species leads to diverse root exudates, which enhance microbial diversity and biomass ${ }^{20}$. Further, plant diversity may increase the soil fungi:bacteria ratio as plant diversity was reported to increase fungal abundance, but not bacterial abundance, in a grassland experiment ${ }^{21}$. Moreover, plant species diversity increases soil moisture by higher leaf area index ${ }^{22}$. As $\mathrm{G}+$ bacteria are more dominant than $\mathrm{G}$ - bacteria in dry conditions due to their thicker cell walls and capacity to form spores $^{23,24}$, the reduced soil moisture associated with lower plant diversity may increase $\mathrm{G}+: \mathrm{G}-$ bacteria ratio. Therefore, our first hypothesis is that plant diversity would increase the total microbial biomass, bacterial and fungal biomass, and fungi:bacteria ratio, but decrease $\mathrm{G}+: \mathrm{G}-$ bacteria ratio due to plant diversity induced increases of carbon inputs and soil moisture 14,17,18,22. $^{2}$.

Plant diversity may affect soil microbial carbon to nitrogen (C:N) ratio and respiration. Soil microbial C:N ratio may increase with plant diversity via increased fungi:bacteria ratio ${ }^{22}$ because fungi tend to have a higher $\mathrm{C}: \mathrm{N}$ ratio than bacteria ${ }^{25,26}$. Additionally, microbial biomass and respiration tend to respond similarly to environmental changes ${ }^{27,28}$, as well as to the variation of plant species diversity ${ }^{29}$. In the meantime, plant diversity may promote microbial metabolic efficiency and decrease microbial metabolic quotient (respiration-to-biomass ratio) by supplying diverse resources for microorganisms and modifying the microenvironment ${ }^{16,30}$. Therefore, our second hypothesis is that plant diversity would increase microbial C: $\mathrm{N}$ ratio and respiration but decrease metabolic quotient because of the effects of plant diversity on the relative abundance of fungi and bacteria ${ }^{22}$, resources available for microorganisms, and the microenvironment ${ }^{16,30}$

The effects of plant diversity on above- and belowground productivity become progressively stronger over time ${ }^{19,31}$. This temporal change of diversity effects has been attributed to increasing interspecific complementarity and decreasing functional redundancy over time $\mathrm{e}^{32,33}$. For microorganisms, there is a time lag in their response to changes in plant communities due to the accumulation of dead plant materials needed before the response of soil microorganisms ${ }^{34,35}$. The results of a long-term grassland experiment revealed that the effect of plant diversity on soil microorganisms was not significant until several years following plot establishment 29,35 . Thus, the divergence of plant diversity effects on microorganisms might have resulted from differences in time/stand ages, and our third hypothesis is that the increases of microbial biomass and respiration with plant diversity would be more pronounced at older stand age due to the time needed for the accumulation of dead plant materials ${ }^{34,35}$.
Plant diversity effects on soil microorganisms may change with ecosystem types and the environment. For example, increases in plant productivity with plant diversity are stronger in nature than documented in experiments ${ }^{36}$. Nevertheless, whether the effects of plant diversity on soil microorganisms differ with ecosystem types varying from planted containers, croplands, planted grasslands, planted forests, and natural forests remain unexplored. Moreover, although a global meta-analysis has shown that the positive effects of tree species diversity and trait heterogeneity on aboveground productivity are consistent across the global forests $^{37}$, regional studies indicate that the positive effects of tree diversity tend to be stronger in colder climates ${ }^{38,39}$. A higher increase in plant productivity with diversity in colder climates may lead to higher amounts of dead plant materials for soil microorganisms and thus stronger increases of soil microbial biomass and respiration with plant diversity.

A previous synthesis of twelve studies in planted grasslands has revealed that soil microbial biomass increases significantly with plant species diversity, particularly in long-term experiments ${ }^{40}$. A previous meta-analysis in croplands found that the addition of one or more crop species to monocultures substantially increased soil microbial biomass ${ }^{41}$. It remains unclear, however, (1) whether the plant diversity effects on soil microbial biomass differ with ecosystem types, and spatially across global terrestrial ecosystems, and (2) how plant diversity influences fungi:bacteria ratio, $\mathrm{G}+\mathrm{G}-$ bacteria ratio, microbial $\mathrm{C}: \mathrm{N}$ ratio, and respiration. We conducted a meta-analysis of 1332 paired observations of plant monocultures and mixtures from 106 studies to investigate the effects of plant diversity on total microbial, bacterial, and fungal biomass, fungi:bacteria ratio, $G+: G-$ bacteria ratio, microbial C:N ratio, respiration, and metabolic quotient across global terrestrial biomes (Fig. 1; Supplementary Table 1, refs. $13,16,20-22,29,35,42-140)$. We expected that: (1) plant mixtures would, on average, increase soil total microbial, bacterial and fungal biomass, fungi:bacteria ratio, microbial $\mathrm{C}: \mathrm{N}$ ratio, and microbial respiration, but decrease $\mathrm{G}+: \mathrm{G}-$ bacteria ratio and metabolic quotient; (2) the effect of plant mixtures would increase with the species richness in mixtures and stand age; (3) the effect of plant mixtures would differ with ecosystem types and change with climate. We show that plant mixtures increase soil total microbial, bacterial and fungal biomass, fungal:bacteria ratio but decrease $\mathrm{G}+: \mathrm{G}-$ bacteria ratio, while having no effects on microbial C:N ratio and metabolic quotient. Moreover, microbial biomass and respiration increase more in mixtures with higher species richness and in older mixtures. These effects of plant mixtures are consistent across ecosystem types and global climates except a higher increase in microbial respiration in colder climates.

\section{Results}

The average effects of plant mixtures on microbial attributes. Across all ecosystem types, total soil microbial biomass increased significantly on average by $12.5 \%$ ( $95 \%$ confidence interval, 7.9-17.1\%; $P<0.001$, Supplementary Table 2), bacterial biomass by $5.2 \%(0.2-10.1 \% ; P=0.054$, Supplementary Table 2$)$, and fungal biomass by $10.9 \%(4.0-17.8 \% ; P=0.004$, Supplementary Table 2) in plant mixtures compared to the mean of constituent monocultures (Fig. 2). Plant mixtures increased fungi:bacteria ratio $(P=0.036$, Supplementary Table 2$)$. Also, plant mixtures, on average, increased soil microbial respiration by $13.2 \%$ (8.1-18.2\%; $P<0.001$, Supplementary Table 2 ). G+:G- bacteria ratio, microbial $\mathrm{C}: \mathrm{N}$ ratio, and metabolic quotient showed no significant responses to plant mixtures (Fig. 2; Supplementary Table 2). 


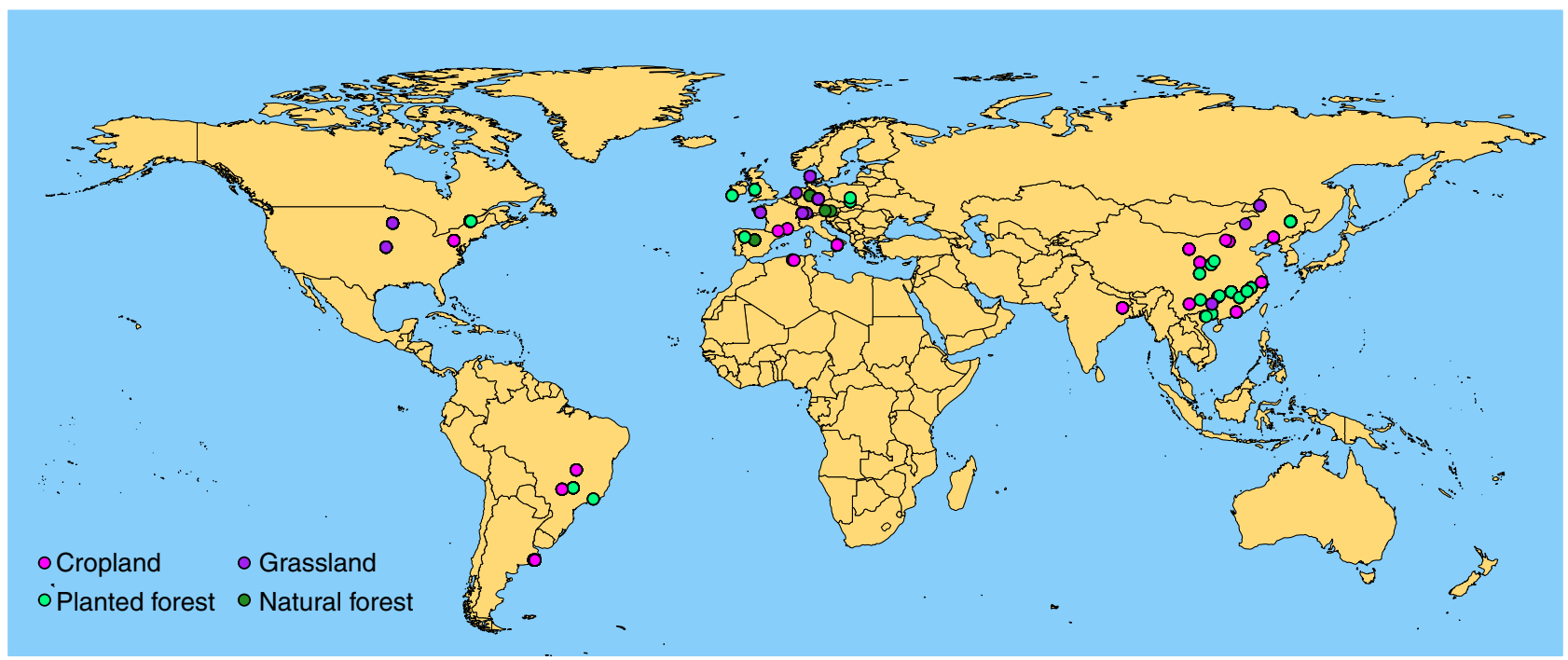

Fig. 1 Global distribution of study sites in the meta-analysis. Magenta, purple, green and dark green points indicate study sites at croplands, grasslands, planted forests and natural forests. Experiments using planted containers were not included in this figure. Source data are provided as a Source Data file

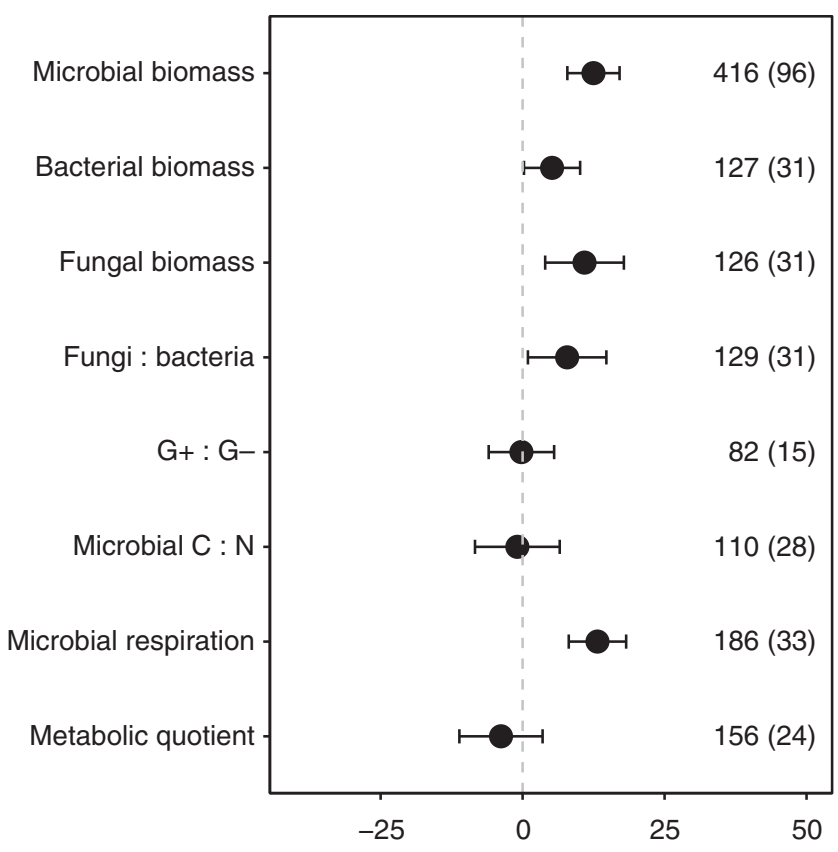

Plant mixture effect on microbial attributes (\%)

Fig. 2 Comparison of soil microbial attributes in plant mixtures versus monocultures. The effects represent the increase or decrease (\%) of a given microbial attribute compared to the corresponding mean of constituent monocultures at the mean species richness and mean stand age in mixtures (see Methods). Values are mean $\pm 95 \%$ confidence intervals of the percentage effects between the plant mixtures and monocultures. The number of observations is shown beside each attribute without parentheses with the number of studies in parentheses. $\mathrm{G}+: \mathrm{G}_{-}$ represents Gram-positive bacteria and Gram-negative bacteria biomass ratio. Source data are provided as a Source Data file

The variation of plant mixture effects. With increasing species richness in plant mixtures, the effect sizes for microbial biomass, bacterial biomass, fungal biomass and microbial respiration significantly increased $(P<0.001, P=0.004, \quad P=0.008$ and $P<0.001$, respectively; Fig. 3a, Supplementary Table 2). The effect size for $\mathrm{G}+: \mathrm{G}-$ bacteria ratio decreased with the species richness
$(P=0.040$, Supplementary Table 2$)$. The effect sizes for microbial biomass and respiration increased with stand age (both $P<0.001)$, and the effect size for fungi:bacteria ratio decreased $(P=0.046)$ (Fig. 3b, Supplementary Table 2). The increases of microbial biomass and respiration with the species richness became more pronounced in older stands (both $P<0.001$ ), but not for other microbial attributes (Fig. 4, Supplementary Table 2).

The plant mixture effect on microbial attributes did not differ significantly among ecosystem types including natural forests, planted forests, planted grasslands, croplands, and planted containers (Supplementary Figure 1). For studies conducted under natural climates (forests and grasslands), the responses of microbial attributes to plant mixtures did not change significantly with mean annual temperature nor aridity index of study sites except microbial respiration. Both the average effect of plant mixtures and the effect of species richness in mixtures on microbial respiration were more pronounced in colder climates $(P<0.001$ for both the average and interaction effects) (Supplementary Figure 2).

Predicted responses of microbial biomass and respiration. Predicted from the fitted species richness- and stand agedependent responses (Fig. 4), a 10\% decrease in plant species richness (from 100 to 90\%) over one year reduced microbial biomass and microbial respiration by $5 \%$. A $40 \%$ decrease in plant species richness (from 100 to $60 \%$ ) over one year led to a $20 \%$ reduction in microbial biomass and microbial respiration (Fig. 5). The declines in microbial biomass and respiration in response to the decrease in plant richness became amplified with longer stand age (Fig. 5). For example, a $10 \%$ decrease in plant species richness (from 100 to $90 \%$ ) over five years led to a $16 \%$ lower microbial biomass (Fig. 5).

\section{Discussion}

Our results demonstrated that plant diversity increased soil microbial biomass across a diverse range of terrestrial ecosystems. Our results extend those derived from twelve grassland studies ${ }^{40}$ to a diverse range of ecosystem types. Importantly, we showed that the plant diversity effect on microbial biomass increased logarithmically with the species richness in mixtures, which coincides with the pattern of the diversity-productivity relationship in the plant community ${ }^{5,7}$. For forests, a $10 \%$ decrease in tree 


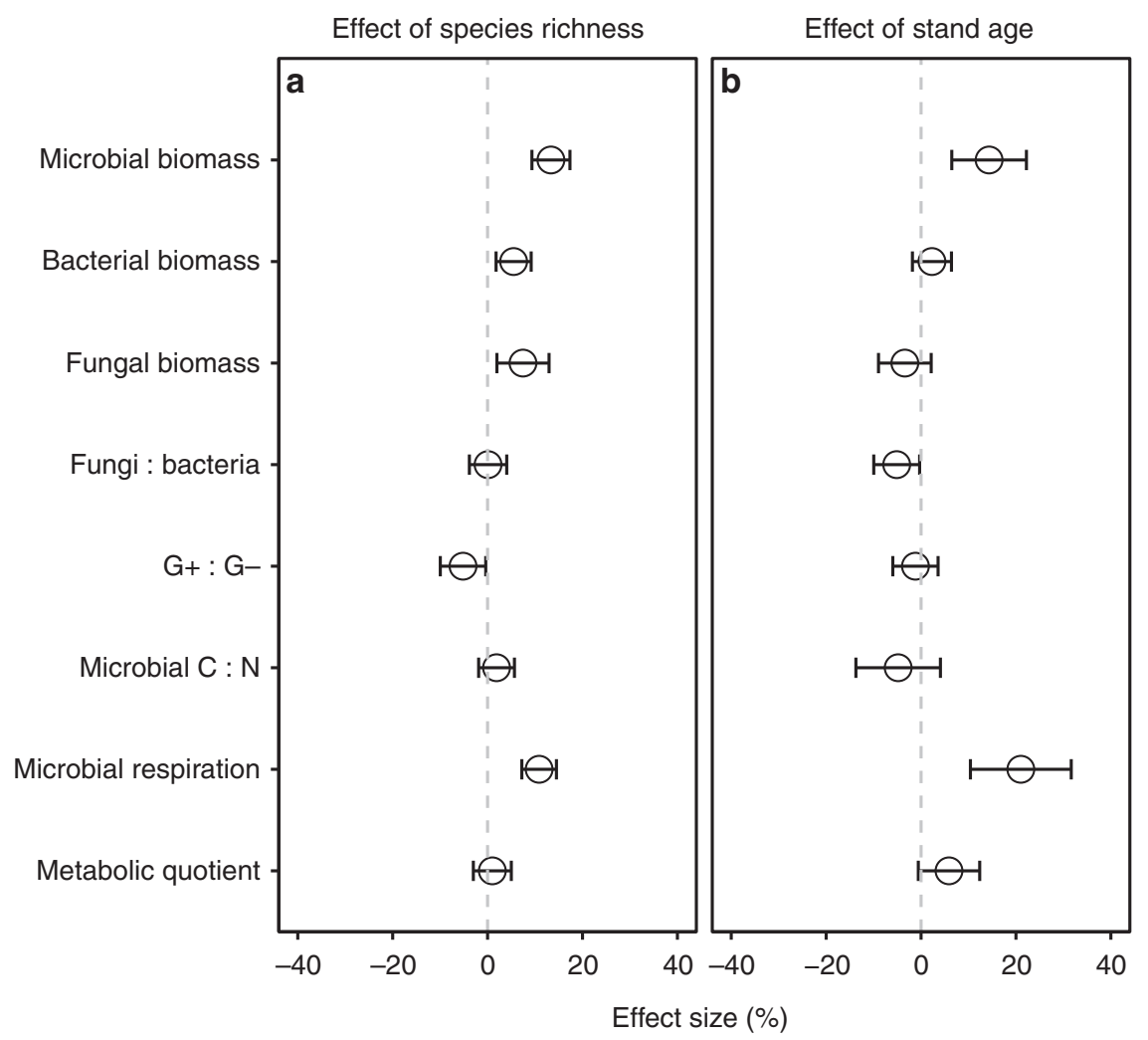

Fig. 3 The effects of plant mixtures on microbial attributes in relation to plant species richness and stand age. a The plant species richness (log scale) in mixtures. $\mathbf{b}$ Stand age (years). The effects represent the estimated coefficients of the species richness in mixtures and stand age. Values (estimated $\beta_{1}$ and $\beta_{2}$ in Equation (3), respectively, see Methods) are mean $\pm 95 \%$ confidence intervals. G+:G- represents Gram-positive and Gram-negative bacteria biomass ratio. Source data are provided as a Source Data file
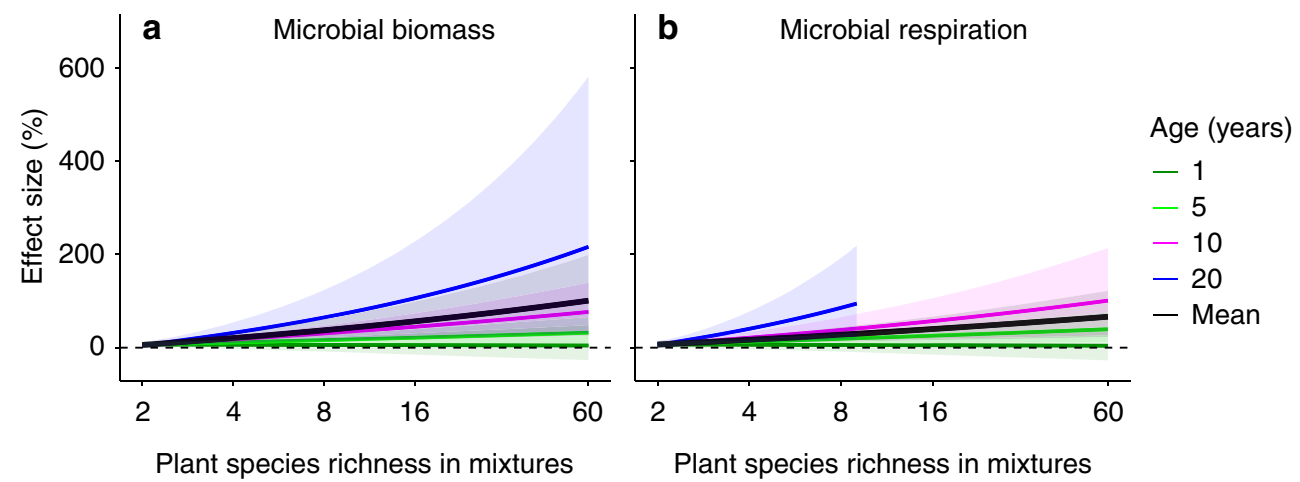

Fig. 4 The interactive effects of the plant species richness in mixtures and stand age on microbial attributes. a Microbial biomass. b Microbial respiration. The effects are quantified as the percent changes in mixtures compared to the corresponding mean value of constituent monocultures. Lines are fitted agedependent regressions with 95\% confidence intervals in shade. Dark green, green, magenta, blue and black lines indicate stand age at 1, 5, 10 and 20 years and mean stand age across all observations. Source data are provided as a Source Data file

species richness (from 100 to $90 \%$ ) is reported to cause a $2-3 \%$ decline in forest productivity ${ }^{7}$. For microbial communities, a $10 \%$ decrease in plant species richness (from 100 to 90\%) over one year causes a $5 \%$ decline in microbial biomass, where the extent of the decline would be larger over the long term. Further, while previous experimental studies showed that plant diversity increased fungal but not bacterial biomass ${ }^{21,22,141}$, our study offers global evidence that the abundance of both bacteria and fungi increase with plant species diversity. This may be attributable to that higher productivity induces more carbon and nutrient inputs to the soil in mixtures, benefitting both fungi and bacteria, as well as the facilitative effect of fungi on the penetration of bacteria into leaf tissue ${ }^{142}$.

Our study offers new insights into the variations of fungi: bacteria ratio and G+:G- bacteria ratio associated with plant species diversity. Although both bacteria and fungi biomass increased with plant diversity, fungi:bacteria ratio was higher in plant mixtures than in monocultures, suggesting that fungi may benefit more from plant species mixture, likely because fungi, but not bacteria, can transfer nutrients from high- to low-nutrient plant litter when plant mixtures include species with different nutrient contents ${ }^{143,144}$. Also, G+:G- bacteria ratio decreased in 

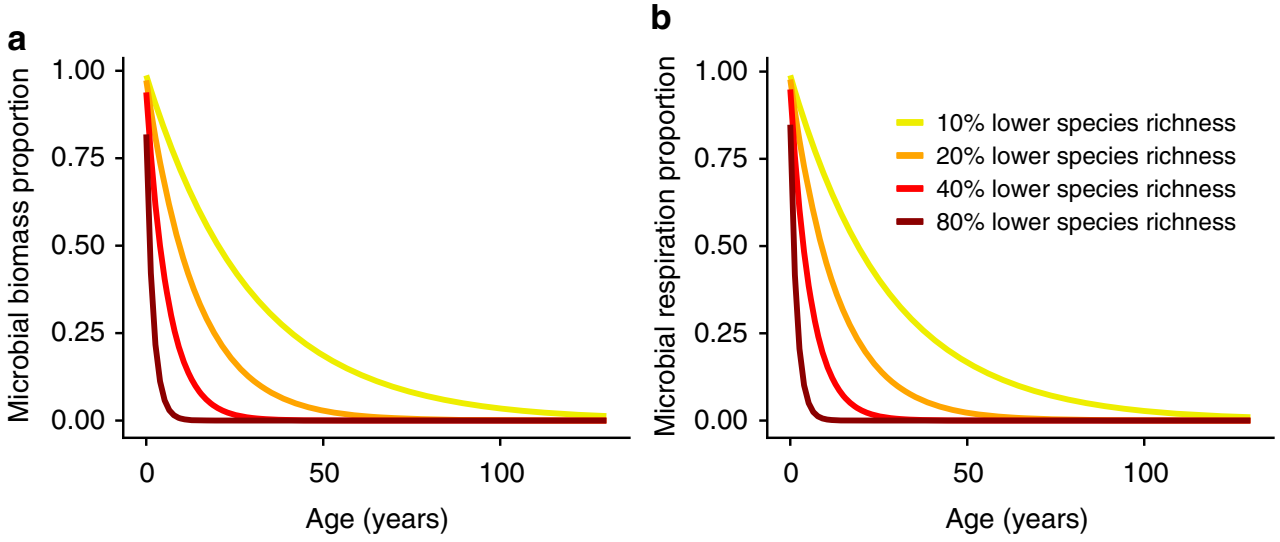

Fig. 5 Predicted responses of microbial attributes to a range of plant species richness reductions. a Microbial biomass. b Microbial respiration. Yellow, orange, red and dark red lines indicate plant species richness reduction at 10, 20, 40 and $80 \%$. Source data are provided as a Source Data file

mixtures, attributable to increased soil moisture with plant diversity 22 , which promotes the relative abundance of $\mathrm{G}-$ bacteria 23,24 . In contrast to our hypothesis, we did not find an effect of plant mixtures on microbial C:N. This is likely because plant diversity increases soil carbon and simultaneously increases nitrogen retention ${ }^{145}$. Consistent with our hypothesis and previous findings ${ }^{29,35}$, we found microbial respiration was higher in plant mixtures.

Our study also showed that the species mixture effects on microbial biomass and respiration increased with the species richness in mixtures and stand age with more pronounced species richness effects in older stands. The increases of soil microbial biomass and respiration with plant species richness were anticipated because soil carbon available for soil microorganisms increases with plant species richness ${ }^{14,17,18}$. The significant interaction effect of species richness and stand age is likely because soil microorganisms show a time lag in their response to plant community after stand establishment ${ }^{34,35}$, and species-rich systems embrace a stronger increase of the plant-derived resources for soil microorganisms over time ${ }^{32}$. Together, our analysis indicates that the lack of plant diversity effects on soil microorganisms in certain studies is attributable to short experimental duration and limited plant species richness. Importantly, our finding indicates that the stronger timedependent effects in species-rich systems do not only occur for ecosystem productivity ${ }^{33}$ but also for soil microbial biomass and respiration. Overall, our study suggests a lasting and deepening effect of plant diversity on microorganisms with increasing stand age.

Although a wide range of ecosystem types were covered, including natural forests, planted forests, planted grasslands, croplands, and planted containers in this study, we found no significant effect of ecosystem types on soil microbial responses to plant mixtures except for a mean annual temperature-dependent response of soil microbial respiration to species mixture under natural climates. The increased species mixture effect on microbial respiration with decreasing mean annual temperature corroborates those of plant productivity to diversity along climate gradients ${ }^{38,39}$. Collectively, these results suggest that the decrease of ecosystem functions of plant and microorganisms with lower plant diversity is more pronounced in colder environments.

Our estimated effects of plant diversity on soil microbial attributes represent plant species complementarity since we factored out selection effects related to plant species composition, following the method by Loreau and Hector ${ }^{146}$. However, among the 106 original studies, 12 studies that reported time-dependent responses had only initial species compositions. Because species compositions can change over time, the log response ratios between plant mixtures and monocultures calculated based on initial species composition could include selection effects associated with temporal changes in species compositions ${ }^{147}$. Nevertheless, a long-term grassland experiment shows that the strength of the complementary effect increases while the selection effect tends to decrease over time ${ }^{33}$. Moreover, we note that previous analyses infer the effects of species diversity loss from experimental studies that manipulated species richness levels ${ }^{6}$. However, time-dependent responses to species diversity could differ between artificially and randomly assembled communities and species loss in natural ecosystems ${ }^{148}$. For this reason, we focus on interpreting the relation between plant species diversity and soil microbial attributes, rather than species loss.

We found that plant species mixtures increased soil microbial biomass, fungal to bacterial biomass ratio, and respiration across global terrestrial ecosystems. We further revealed that these effects increased with the number of species in mixtures and stand age. While the responses of soil microbial attributes to plant diversity corroborate with those of plant productivity, they were higher in magnitude than those of plant productivity. Moreover, our findings indicate that the increase of microbial respiration with plant diversity was more pronounced under a colder climate. Because of the dominant control of soil microorganisms on element cycling ${ }^{1-4}$, our results suggest that declines in soil microbial biomass and respiration, coupled with the shift in the relative abundance of soil fungi and bacteria induced by lower plant diversity, could have profound adverse effects on the global carbon and nutrients cycles. These adverse effects could amplify with further decreases in plant diversity and longer stand age.

\section{Methods}

Data collection. We systematically searched all peer-reviewed journal articles and theses that investigated the effects of plant diversity on microbial biomass, fungi: bacteria ratio, $\mathrm{G}+: \mathrm{G}-$ bacteria ratio, microbial C:N ratio and respiration, using the Web of Science and Google Scholar, up to 1st November, 2018. The literature search was performed following guidelines from PRISMA (Preferred Reporting Items for Systematic Reviews and Meta-Analyses; ${ }^{149}$ Supplementary Figure 3). Various keyword combinations were used for the search, such as (species diversity OR tree diversity OR richness OR mix species OR mix tree OR mixture OR intercrop) AND (microbial abundance OR microbial biomass OR microbe OR microbial OR soil biota OR microbial community OR fungi OR bacteria OR microbial biomass nitrogen OR microbial respiration $\mathrm{OR}$ basal respiration $\mathrm{OR}$ microbial activity). We reviewed each article to determine whether the studies met the following criteria: (1) isolated the effects of plant diversity from other factors, such as stand age and topography; (2) the microbial attributes could be extracted directly from the text, tables, and figures. 
When different publications included the same data from one study, we recorded the data only once. When a study included plant mixtures of different numbers of species, we considered them distinct observations. Also, when a publication included several experiments under different abiotic conditions, such as different locations, treatments, stand ages, and soil layers, we considered them different observations. We used Plot Digitizer version 2.0 (Department of Physics at the University of South Alabama, Mobile, AL, USA) to digitally extract data from figures when the results were graphically reported. We obtained a meta-dataset of 1332 observations from 106 studies (Supplementary Table 1) that involved the mixing of live plants in natural forests, planted forests, planted grasslands, croplands, and planted containers (Fig. 1)

For each study, we extracted microbial attributes including microbial biomass, bacterial biomass, fungal biomass, fungi:bacteria ratio, $\mathrm{G}+\mathrm{G}-\mathrm{G}$ bacteria ratio, microbial C:N ratio, microbial respiration, and metabolic quotient. Methods for determining the microbial biomass included the measurement of microbial biomass carbon via a substrate-induced respiration method ${ }^{150}$, fumigationextraction method ${ }^{151}$, measuring the total amounts of phospholipid fatty acid (PLFA) in the soil ${ }^{152}$, as well as the investigation of microbial quantities via a quantitative polymerase chain reaction (qPCR). Metabolic quotient was calculated as the respiration rate per unit microbial biomass.

We obtained plant species richness, species identity, the species proportions in plant mixtures, geographical location (latitude, longitude, and altitude), ecosystem type, stand age, and soil sampling depth (as middle value of each sampling depth interval ${ }^{153}$ ) from original publications. The species proportions in plant mixtures were based on basal area, stem density, or crown cover in forests, coverage or sowing seeds in grasslands, and the number of individuals in other systems. In 3 of the 106 studies, species proportions were unavailable in the publications, and we assumed they were equal for all constituent species. The stand age referred to the years between stand establishment or experiment initiation and the measurement of soil microbial attributes. For those studies conducted under natural climates including forests and grasslands, we obtained mean annual temperature for each study site from original publications; when unavailable, it was derived based on geographic locations using the WorldClim version 2 dataset $^{154}$. Similarly, we derived the aridity index (calculated as mean annual precipitation divided by mean annual potential evapotranspiration, where a higher aridity index indicated lower aridity) for each site from the Global Aridity and PET Database ${ }^{155}$.

Data analysis. We used a natural $\log$-transformed response ratio $(\ln R R)$ as the effect size to assess the responses of soil microbial attributes to plant mixtures ${ }^{156}$. The $\ln R R$ was calculated as:

$$
\ln R R=\ln \left(X_{t} / X_{c}\right)
$$

where $X_{t}$ and $X_{c}$ are the observed and expected values in a mixture, respectively. To take account of the species compositional effect (or selection effect), we calculated the $X_{c}$ as the weighted values of the constituent species in monocultures following Loreau and Hector ${ }^{146}$, in which weights represent the species proportions in the mixture. Therefore, our estimated $\ln R R$ represents the complementarity effect of species mixtures. Within each study, $\ln R R$ was calculated separately for each species diversity level and stand age.

In the meta-analyses, effect size estimates and subsequent inferences may be dependent on how the individual observations are weighted. Weightings based on sampling variances might assign extreme importance to a few individual observations, and consequently, the average $\ln R R$ would be mainly determined by a small number of studies. Similar to the previous studies ${ }^{31,157}$, we used the number of replications for weighting:

$$
W_{r}=\left(N_{c} \times N_{t}\right) /\left(N_{c}+N_{t}\right)
$$

where $W_{r}$ is the weight for each observation and $N_{t}$ and $N_{c}$ are the numbers of replications in the plant mixtures and the corresponding monocultures, respectively.

For each microbial attribute, we tested whether its response to plant mixtures differed from zero and whether $\ln R R$ was affected by plant species richness $(R)$, stand age ( $A$, years), and ecosystem type $(E)$ using the following model:

$$
\begin{array}{r}
\ln R R=\beta_{0}+\beta_{1} \cdot R+\beta_{2} \cdot A+\beta_{3} \cdot R \times A+\beta_{4} \cdot E+\beta_{5} \cdot R \times E+\beta_{6} \cdot A \times E \\
+\beta_{7} \cdot R \times A \times E+\pi_{\text {study }}+\epsilon
\end{array}
$$

where $\beta$ is the coefficient to be estimated; $\pi_{\text {study }}$ is the random effect factor of study, accounting for the autocorrelation among observations within each study; $\varepsilon$ is sampling error. We conducted the analysis using restricted maximum likelihood estimation with the lme4 package with $W_{r}$ as the weight for each corresponding observation ${ }^{158}$. To prevent overfitting ${ }^{159}$, we selected the most parsimonious model among all alternatives with the condition to keep $R$ and $A$, as they were part of our core hypotheses to be tested. The model selection was accomplished by using the 'dredge' function of the MuMIn package ${ }^{160}$. All terms associated with ecosystem type (Equation 3) were excluded in the most parsimonious models (Supplementary Table 2). To further examine the effects of ecosystem types, we conducted an analysis with the ecosystem type as the only fixed factor and study as the random factor, and the analysis confirmed that there was no difference in the microbial responses among ecosystem types (Supplementary Figure 1). We assessed the assumption of linearity between $\ln R R$ and continuous predictors by comparing linear and $\log$-linear responses. Natural $\log$ transformed $R, \ln (R)$, yielded lower or similar Akaike information criterion (AIC) values than $R$, whereas $A$ was better than $\ln (A)$ (Supplementary Table 3).

We scaled all continuous predictors (observed values minus mean and divided by one standard deviation). When continuous predictors are scaled, $\beta_{0}$ is the overall mean $\ln R R$ at the mean $\ln (R)$ and mean $A^{161}$. To graphically illustrate whether the effect of the species richness in mixtures on $\ln R R$ differed with stand age, we calculated age-dependent effects using the recommended method ${ }^{161}$ at stand ages of $1,5,10$, and 20 years, respectively. While the stand age of our dataset ranged to 130 years, the trend for the stand age over 20 years was not shown since only two species mixtures and corresponding monocultures were studied for stands older than 20 years.

For studies conducted under natural climates including forests and grasslands, we examined whether mean annual temperature and aridity index of study sites affected the responses of microbial attributes to the effects of the species richness in the mixtures and stand age by substituting $E$ in Equation (3) by mean annual temperature and aridity index, respectively. Similarly, we selected the most parsimonious models using the method described above. All terms associated with mean annual temperature and aridity index were excluded during the model selection except for microbial respiration. The response of microbial respiration to plant mixtures was mean annual temperature-dependent (Supplementary Figure 2).

For ease of interpretation, $\ln R R$ and its corresponding $95 \%$ confidence intervals (CIs) were transformed to a percentage change between monocultures and mixtures as

$$
\left(e^{\ln R R}-1\right) \times 100 \%
$$

i.e., overyielding from species complementarity ${ }^{146}$. If the CIs did not cover zero, the effect of species mixture on microbial attributes differed significantly at $\alpha=0.05$ between monocultures and mixtures.

To illustrate the effects of plant diversity on microbial biomass and respiration over time, we compared the $\ln R R$ when the plant richness in mixtures was $R_{1}$ (all species present) and $R_{\alpha}$ ( $\alpha \%$ lower species richness). We assumed that the mean value of monocultures, $X_{c}$, did not vary with the number of monocultures of different species, which led to the following equation:

$$
P_{\alpha}=\left(R_{\alpha} / R_{1}\right)^{\beta_{1}+\beta_{3} \cdot T}
$$

where $P_{\alpha}$ is the proportion of remaining microbial biomass or respiration under $\alpha \%$ lower plant species richness in a period of $T$, and other model terms were described in Equation (3). The detailed derivation process for Equation (5) is presented in Supplementary Methods. Based on Equation (5), we fitted curves for the decrease in microbial biomass and respiration over time when there was a 10 , 20,40 , and $80 \%$ decrease in plant species richness.

We examined whether the responses to plant mixtures differed with the technical methods for the determination of microbial biomass, bacterial biomass, fungal biomass, and fungal:bacterial biomass ratio. The technical methods showed insignificant effects on the effect size of plant mixture effects on microbial attributes (Supplementary Table 4). We also tested whether the responses to plant mixtures differed with soil depth, and we found consistent responses across all sampling depths (Supplementary Table 5). All analyses were performed in R 3.5.2 162

Reporting summary. Further information on experimental design is available in the Nature Research Reporting Summary linked to this article.

\section{Code availability}

The R scripts needed to reproduce the analysis is available as Supplementary Software.

\section{Data availability}

The source data underlying Figs. 1-5 and Supplementary Figures 1-2 and Supplementary Tables 1-5 are provided as a Source Data file.

Received: 8 September 2018 Accepted: 1 March 2019 Published online: 22 March 2019

\section{References}

1. Bardgett, R. D. \& van der Putten, W. H. Belowground biodiversity and ecosystem functioning. Nature 515, 505-511 (2014).

2. Karhu, K. et al. Temperature sensitivity of soil respiration rates enhanced by microbial community response. Nature 513, 81-84 (2014).

3. Delgado-Baquerizo, M. et al. A global atlas of the dominant bacteria found in soil. Science 359, 320-325 (2018).

4. Naeem, S., Hahn, D. R. \& Schuurman, G. Producer-decomposer codependency influences biodiversity effects. Nature 403, 762-764 (2000). 
5. Tilman, D. \& Lehman, C. Human-caused environmental change: impacts on plant diversity and evolution. Proc. Natl. Acad. Sci. USA 98, 5433-5440 (2001).

6. Cardinale, B. J. et al. Biodiversity loss and its impact on humanity. Nature 486, 59-67 (2012)

7. Liang, J. et al. Positive biodiversity-productivity relationship predominant in global forests. Science 354, aaf8957 (2016).

8. Wardle, D. A. et al. Ecological linkages between aboveground and belowground biota. Science 304, 1629-1633 (2004).

9. Barberán, A. et al. Relating belowground microbial composition to the taxonomic, phylogenetic, and functional trait distributions of trees in a tropical forest. Ecol. Lett. 18, 1397-1405 (2015).

10. Teste, F. P. et al. Plant-soil feedback and the maintenance of diversity in Mediterranean-climate shrublands. Science 355, 173-176 (2017).

11. Berg, G. \& Smalla, K. Plant species and soil type cooperatively shape the structure and function of microbial communities in the rhizosphere. FEMS Microbiol. Ecol. 68, 1-13 (2009).

12. Leff, J. W. et al. Predicting the structure of soil communities from plant community taxonomy, phylogeny, and traits. ISME J. 12, 1794-1805 (2018).

13. Zak, D. R., Holmes, W. E., White, D. C., Peacock, A. D. \& Tilman, D. Plant diversity, soil microbial communities, and ecosystem function: are there any links? Ecology 84, 2042-2050 (2003).

14. Lange, M. et al. Plant diversity increases soil microbial activity and soil carbon storage. Nat. Commun. 6, 6707 (2015).

15. Milcu, A., Partsch, S., Scherber, C., Weisser, W. W. \& Scheu, S. Earthworms and legumes control litter decomposition in a plant diversity gradient. Ecology 89, 1872-1882 (2008).

16. Eisenhauer, N. et al. Plant diversity effects on soil food webs are stronger than those of elevated $\mathrm{CO}_{2}$ and $\mathrm{N}$ deposition in a long-term grassland experiment. Proc. Natl. Acad. Sci. USA 110, 6889-6894 (2013).

17. Khlifa, R., Paquette, A., Messier, C., Reich, P. B. \& Munson, A. D. Do temperate tree species diversity and identity influence soil microbial community function and composition? Ecol. Evol. 7, 7965-7974 (2017).

18. Ma, Z. \& Chen, H. Y. H. Positive species mixture effects on fine root turnover and mortality in natural boreal forests. Soil Biol. Biochem. 121, 130-137 (2018).

19. Tilman, D. et al. Diversity and productivity in a long-term grassland experiment. Science 294, 843-845 (2001).

20. Steinauer, K., Chatzinotas, A. \& Eisenhauer, N. Root exudate cocktails: the link between plant diversity and soil microorganisms? Ecol. Evol. 6, 7387-7396 (2016).

21. Chung, H., Zak, D. R., Reich, P. B. \& Ellsworth, D. S. Plant species richness, elevated $\mathrm{CO}_{2}$, and atmospheric nitrogen deposition alter soil microbial community composition and function. Glob. Change Biol. 13 980-989 (2007).

22. Lange, M. et al. Biotic and abiotic properties mediating plant diversity effects on soil microbial communities in an experimental grassland. PLOS ONE $\mathbf{9}$, e96182 (2014)

23. Bérard, A., Bouchet, T., Sévenier, G., Pablo, A. L. \& Gros, R. Resilience of soil microbial communities impacted by severe drought and high temperature in the context of Mediterranean heat waves. Eur. J. Soil Biol. 47, 333-342 (2011).

24. Escobar, I. E. C. et al. Changes in microbial community structure and soil biological properties in mined dune areas during re-vegetation. Environ. Manag. 55, 1433-1445 (2015).

25. Mouginot, C. et al. Elemental stoichiometry of Fungi and Bacteria strains from grassland leaf litter. Soil Biol. Biochem. 76, 278-285 (2014).

26. Chen, Y.-L. et al. Linking microbial C:N:P stoichiometry to microbial community and abiotic factors along a $3500-\mathrm{km}$ grassland transect on the Tibetan Plateau. Glob. Ecol. Biogeogr. 25, 1416-1427 (2016).

27. Holden, S. \& Treseder, K. A meta-analysis of soil microbial biomass responses to forest disturbances. Front. Microbiol. 4, 163 (2013).

28. Zhang, T., Chen, H. Y. H. \& Ruan, H. Global negative effects of nitrogen deposition on soil microbes. ISME J. 12, 1817-1825 (2018)

29. Strecker, T., Macé, O. G., Scheu, S. \& Eisenhauer, N. Functional composition of plant communities determines the spatial and temporal stability of soil microbial properties in a long-term plant diversity experiment. Oikos 125, 1743-1754 (2016).

30. Bardgett, R. D. \& Shine, A. Linkages between plant litter diversity, soil microbial biomass and ecosystem function in temperate grasslands. Soil Biol. Biochem. 31, 317-321 (1999).

31. Ma, Z. \& Chen, H. Y. H. Effects of species diversity on fine root productivity in diverse ecosystems: a global meta-analysis. Glob. Ecol. Biogeogr. 25, 1387-1396 (2016).

32. Meyer, S. T. et al. Effects of biodiversity strengthen over time as ecosystem functioning declines at low and increases at high biodiversity. Ecosphere 7, e01619 (2016).

33. Reich, P. B. et al. Impacts of biodiversity loss escalate through time as redundancy fades. Science 336, 589-592 (2012).
34. Bartelt-Ryser, J., Joshi, J., Schmid, B., Brandl, H. \& Balser, T. Soil feedbacks of plant diversity on soil microbial communities and subsequent plant growth. Perspect. Plant Ecol. Evol. Syst. 7, 27-49 (2005).

35. Eisenhauer, N. et al. Plant diversity effects on soil microorganisms support the singular hypothesis. Ecology 91, 485-496 (2010).

36. Duffy, J. E., Godwin, C. M. \& Cardinale, B. J. Biodiversity effects in the wild are common and as strong as key drivers of productivity. Nature 549, 261-264 (2017).

37. Zhang, Y., Chen, H. Y. H. \& Reich, P. B. Forest productivity increases with evenness, species richness and trait variation: a global meta-analysis. J. Ecol. 100, 742-749 (2012).

38. Paquette, A. \& Messier, C. The effect of biodiversity on tree productivity: from temperate to boreal forests. Glob. Ecol. Biogeogr. 20, 170-180 (2011)

39. Ratcliffe, S. et al. Modes of functional biodiversity control on tree productivity across the European continent. Glob. Ecol. Biogeogr. 25, 251-262 (2016).

40. Thakur, M. P. et al. Plant diversity drives soil microbial biomass carbon in grasslands irrespective of global environmental change factors. Glob. Change Biol. 21, 4076-4085 (2015).

41. McDaniel, M. D., Tiemann, L. K. \& Grandy, A. S. Does agricultural crop diversity enhance soil microbial biomass and organic matter dynamics? A meta-analysis. Ecol. Appl. 24, 560-570 (2014).

42. Alvarez, G., Chaussod, R., Loiseau, P. \& Delpy, R. Soil indicators of C and N transformations under pure and mixed grass-clover swards. Eur. J. Agron. 9, 157-172 (1998)

43. Bagherzadeh, A., Brumme, R. \& Beese, F. Temperature dependence of nitrogen mineralization and microbial status in $\mathrm{O}_{\mathrm{H}}$ horizon of a temperate forest ecosystem. J. For. Res. 19, 37-43 (2008).

44. Berger, T. W., Inselsbacher, E. \& Zechmeister-Boltenstern, S. Carbon dioxide emissions of soils under pure and mixed stands of beech and spruce, affected by decomposing foliage litter mixtures. Soil Biol. Biochem. 42, 986-997 (2010).

45. Bini, D., dos Santos, C. A., Bouillet, J. P., Goncalves, J. L. D. \& Cardoso, E. Eucalyptus grandis and Acacia mangium in monoculture and intercropped plantations: Evolution of soil and litter microbial and chemical attributes during early stages of plant development. Appl. Soil Ecol. 63, 57-66 (2013).

46. Borken, W. \& Beese, F. Soil respiration in pure and mixed stands of European beech and Norway spruce following removal of organic horizons. Can. J. For. Res. 35, 2756-2764 (2005).

47. Cesarz, S. et al. Roots from beech (Fagus sylvatica L.) and ash (Fraxinus excelsior L.) differentially affect soil microorganisms and carbon dynamics. Soil Biol. Biochem. 61, 23-32 (2013).

48. Chen, J. \& Yang, N. Effects of five plantations on soil properties in subtropical red soil hilly region (in Chinese with English abstract). J. Northwest A\&F Univ. (Nat. Sci. Ed.) 41, 167-173 (2013).

49. Chen, M. M., Chen, B. D. \& Marschner, P. Plant growth and soil microbial community structure of legumes and grasses grown in monoculture or mixture. J. Environ. Sci. (China) 20, 1231-1237 (2008).

50. Chen, M. M. et al. Effects of soil moisture and plant interactions on the soil microbial community structure. Eur. J. Soil Biol. 43, 31-38 (2007).

51. Chodak, M. \& Niklinska, M. Effect of texture and tree species on microbial properties of mine soils. Appl. Soil Ecol. 46, 268-275 (2010).

52. Chodak, M. \& Niklinska, M. The effect of different tree species on the chemical and microbial properties of reclaimed mine soils. Biol. Fertil. Soils $\mathbf{4 6}$ 555-566 (2010).

53. Cong, W.-F. \& Eriksen, J. Forbs differentially affect soil microbial community composition and functions in unfertilized ryegrass-red clover leys. Soil Biol. Biochem. 121, 87-94 (2018).

54. Coser, T. R. et al. Soil microbiological properties and available nitrogen for corn in monoculture and intercropped with forage. Pesqui. Agrop. Bras. 51, 1660-1667 (2016).

55. De Deyn, G. B., Quirk, H. \& Bardgett, R. D. Plant species richness, identity and productivity differentially influence key groups of microbes in grassland soils of contrasting fertility. Biol. Lett. 7, 75-78 (2011).

56. Diaz-Pines, E. et al. Effects of tree species composition on the $\mathrm{CO}_{2}$ and $\mathrm{N}_{2} \mathrm{O}$ efflux of a Mediterranean mountain forest soil. Plant Soil 384, 243-257 (2014).

57. Dijkstra, F. A., Hobbie, S. E., Reich, P. B. \& Knops, J. M. H. Divergent effects of elevated $\mathrm{CO}_{2}, \mathrm{~N}$ fertilization, and plant diversity on soil $\mathrm{C}$ and $\mathrm{N}$ dynamics in a grassland field experiment. Plant Soil 272, 41-52 (2005).

58. Dong, M. et al. Soil microbial biomass $\mathrm{C}, \mathrm{N}$ and diversity characteristics in pure and mixed forest of Pinusand Cinnamomun (in Chinese with English abstract). J. Centr. South Univ. For. \& Techn. 37, 146-153 (2017).

59. Drissner, D., Blum, H., Tscherko, D. \& Kandeler, E. Nine years of enriched $\mathrm{CO}_{2}$ changes the function and structural diversity of soil microorganisms in a grassland. Eur. J. Soil Sci. 58, 260-269 (2007).

60. Du, C. Effects Of Potato/maize Intercropping On Soil and Crops (in Chinese with English abstract). Master's thesis, Ningxia University (2017).

61. Duo, Y., Wang, G., Yan, W. \& Liu, L. The biomass comparison of soil microbial carbon and nitrogen of 3 kinds of forest types in subtropics (in Chinese with English abstract). Chin. Agric. Sci. Bull. 28, 14-19 (2012). 
62. Eisenhauer, N. et al. Root biomass and exudates link plant diversity with soil bacterial and fungal biomass. Sci. Rep. 7, 44641 (2017).

63. Fan, F. L., Zhang, F. S., Qu, Z. \& Lu, Y. H. Plant carbon partitioning below ground in the presence of different neighboring species. Soil Biol. Biochem. 40, 2266-2272 (2008)

64. Fan, S. \& Yang, N. Comparsion of soil microbiology characteristics in five subtropical ecosystems (in Chinese with English abstract). J. Trop. Subtrop. Bot. 24, 635-641 (2016).

65. Fang, S. Z., Liu, D., Tian, Y., Deng, S. P. \& Shang, X. L. Tree species composition influences enzyme activities and microbial biomass in the rhizosphere: a rhizobox approach. PLoS ONE 8, e61461 (2013).

66. Finney, D. M., Buyer, J. S. \& Kaye, J. P. Living cover crops have immediate impacts on soil microbial community structure and function. J. Soil Water Conserv. 72, 361-373 (2017)

67. Gong, J. R. et al. Effect of irrigation on the soil respiration of constructed grasslands in Inner Mongolia, China. Plant Soil 395, 159-172 (2015).

68. Gunina, A., Smith, A. R., Godbold, D. L., Jones, D. L. \& Kuzyakov, Y. Response of soil microbial community to afforestation with pure and mixed species. Plant Soil 412, 357-368 (2017).

69. He, Y. et al. Profiling of microbial PLFAs: Implications for interspecific interactions due to intercropping which increase phosphorus uptake in phosphorus limited acidic soils. Soil Biol. Biochem. 57, 625-634 (2013).

70. Hu, B. et al. Comparison of nitrogen nutrition and soil carbon status of afforested stands established in degraded soil of the Loess Plateau, China. For. Ecol. Manag. 389, 46-58 (2017).

71. Hu, Y., Zhai, M., Wu, J. \& Jia, L. Seasonal dynamics of amount and biochemical activity of soil microorganisms in pure and mixed stands of poplar and black locust (in Chinese). Soils 34, 42-46 (2002).

72. Huang, Y. et al. Changes in soil quality due to introduction of broad-leaf trees into clear-felled Chinese fir forest in the mid-subtropics of China. Soil Use Manag. 20, 418-425 (2004).

73. Jiang, Y. M., Chen, C. R., Liu, Y. Q. \& Xu, Z. H. Soil soluble organic carbon and nitrogen pools under mono- and mixed species forest ecosystems in subtropical China. J. Soils Sed. 10, 1071-1081 (2010).

74. Khlifa, R. Effets de la diversité des arbres sur le fonctionnement de l'écosystème dans deux plantations de forêts tempérées. Ph.D. Dissertation, Université Laval Québec Canada (2016).

75. Kong, C.-H., Wang, M.-L., Wang, P., Ni, H.-W. \& Meng, X.-R. Reproduction allocation and potential mechanism of individual allelopathic rice plants in the presence of competing barnyardgrass. Pest Manag. Sci. 69, 142-148 (2012).

76. Ladygina, N. \& Hedlund, K. Plant species influence microbial diversity and carbon allocation in the rhizosphere. Soil Biol. Biochem. 42, 162-168 (2010).

77. Latati, M. et al. Intercropping maize and common bean enhances microbial carbon and nitrogen availability in low phosphorus soil under Mediterranean conditions. Eur. J. Soil Biol. 80, 9-18 (2017).

78. Leloup, J. et al. Unravelling the effects of plant species diversity and aboveground litter input on soil bacterial communities. Geoderma 317, 1-7 (2018).

79. $\mathrm{Li}, \mathrm{Q}$. et al. Biochemical and microbial properties of rhizospheres under maize/peanut intercropping. J. Inter. Agric. 15, 101-110 (2016).

80. Li, X. et al. Effects of plant community composition on microbial community in constructed wetlands (in Chinese with English abstract). Chin. J. Ecol. 33, 1508-1514 (2014).

81. Liu, J. et al. Effects of tree species and soil properties on the composition and diversity of the soil bacterial community following afforestation. For. Ecol. Manag. 427, 342-349 (2018).

82. Liu, M., Hu, F., He, Y. \& Li, H. Seasonal dynamics of soil microbial biomass and its significance to indicate soil quality under different vegetations restored on degraded red soils (in Chinese with English abstract). Acta Pedol. Sin. 40, 937-944 (2003).

83. Liu, Y., Yang, J., Du, T. \& Nie, G. Effect of rehabilitated forest on soil microbial characteristics of severely degraded red soil region (in Chinese with English abstract). J. Fujian Colleg. For. 23, 65-69 (2003).

84. Liuzhuo, M., Liu, Z., Feng, S. \& Duan, E. Soil biological characteristics in different kinds of artificial forests in the semi-humid zones of loess plateau (in Chinese with English abstract). J. Northwest For. Univ. 24, 26-31 (2009).

85. Luo, D. et al. Impacts of nitrogen-fixing and non-nitrogen-fixing tree species on soil respiration and microbial community composition during forest management in subtropical China. Ecol. Res. 31, 683-693 (2016).

86. Luo, D., Shi, Z., Tang, J., Liu, S. \& Lu, L. Soil microbial community structure of monoculture and mixed plantation stands of native tree species in south subtropical China (in Chinese with English abstract). Chin. J. Appl. Ecol. 25, 2543-2550 (2014).

87. Malchair, S. et al. Do climate warming and plant species richness affect potential nitrification, basal respiration and ammonia-oxidizing bacteria in experimental grasslands? Soil Biol. Biochem. 42, 1944-1951 (2010).
88. Oelbermann, M. \& Echarte, L. Evaluating soil carbon and nitrogen dynamics in recently established maize-soyabean inter-cropping systems. Eur. J. Soil Sci. 62, 35-41 (2011).

89. Oelbermann, M., Regehr, A. \& Echarte, L. Changes in soil characteristics after six seasons of cereal-legume intercropping in the Southern Pampa. Geoderma Reg. 4, 100-107 (2015).

90. Orwin, K. H. \& Wardle, D. A. Plant species composition effects on belowground properties and the resistance and resilience of the soil microflora to a drying disturbance. Plant Soil 278, 205-221 (2005).

91. Pan, H. Soil Carbon and Nitrogen Transformation Process Research of Relationship Between Soilo Microbial Community Structure of Michelia Macclurei, Pinus Massoniana Plantation (in Chinese with English abstract). Master's thesis, Guangxi University (2015).

92. Pausch, J., Zhu, B., Kuzyakov, Y. \& Cheng, W. Plant inter-species effects on rhizosphere priming of soil organic matter decomposition. Soil Biol. Biochem. 57, 91-99 (2013).

93. Pereira, E. L., Santos, S. A. P., Arrobas, M. \& Patricio, M. S. Microbial biomass and $\mathrm{N}$ mineralization in mixed plantations of broadleaves and nitrogen-fixing species. For. Syst. 20, 516-524 (2011)

94. Porazinska, D. L. et al. Relationships at the aboveground-belowground interface: plants, soil biota, and soil processes. Ecol. Monogr. 73, 377-395 (2003).

95. Qu, J. Effects of Intercropping Oat and Common Vetch on Forage Yield and Quality and Soil Characteristics (in Chinese with English abstract). Master's thesis, Inner Mongolia Agricultural University (2017).

96. Rachid, C. T. C. C. et al. Mixed plantations can promote microbial integration and soil nitrate increases with changes in the $\mathrm{N}$ cycling genes. Soil Biol. Biochem. 66, 146-153 (2013).

97. Rivest, D., Paquette, A., Shipley, B., Reich, P. B. \& Messier, C. Tree communities rapidly alter soil microbial resistance and resilience to drought. Funct. Ecol. 29, 570-578 (2015)

98. Salamon, J. A. \& Alphei, J. The collembola community of a central European forest: influence of tree species composition. Eur. J. Soil Biol. 45, 199-206 (2009).

99. Sanaullah, M., Blagodatskaya, E., Chabbi, A., Rumpel, C. \& Kuzyakov, Y. Drought effects on microbial biomass and enzyme activities in the rhizosphere of grasses depend on plant community composition. Appl. Soil Ecol. 48, 38-44 (2011).

100. Scalise, A., Pappa, V. A., Gelsomino, A. \& Rees, R. M. Pea cultivar and wheat residues affect carbon/nitrogen dynamics in pea-triticale intercropping: A microcosms approach. Sci. Total Environ. 592, 436-450 (2017).

101. Scalise, A. et al. Legume-barley intercropping stimulates soil $\mathrm{N}$ supply and crop yield in the succeeding durum wheat in a rotation under rainfed conditions. Soil Biol. Biochem. 89, 150-161 (2015).

102. Scheu, S. et al. The soil fauna community in pure and mixed stands of beech and spruce of different age: trophic structure and structuring forces. Oikos 101, 225-238 (2003).

103. Sharma, R. C. \& Banik, P. Baby corn-legumes intercropping systems: I. Yields, resource utilization efficiency, and soil health. Agroecol. Sust. Food Syst. 39, 41-61 (2015)

104. Song, Y. N. et al. Effect of intercropping on crop yield and chemical and microbiological properties in rhizosphere of wheat (Triticum aestivum L.), maize (Zea mays L.), and faba bean (Vicia faba L.). Biol. Fertil. Soils 43, 565-574 (2007).

105. Sørensen, L. I., Mikola, J. \& Kytöviita, M.-M. Defoliation effects on plant and soil properties in an experimental low arctic grassland community - the role of plant community structure. Soil Biol. Biochem. 40, 2596-2604 (2008).

106. Souza, M. F. P., da Silva, M. P., Arf, O. \& Cassiolato, A. M. R. Chemical and biological properties of phosphorus-fertilized soil under legume and grass cover (Cerrado region, Brazil). Rev. Bras. Ciênc. Solo 37, 1492-1501 (2013).

107. Spehn, E. M., Joshi, J., Schmid, B., Alphei, J. \& Körner, C. Plant diversity effects on soil heterotrophic activity in experimental grassland ecosystems. Plant Soil 224, 217-230 (2000).

108. Spohn, M. \& Chodak, M. Microbial respiration per unit biomass increases with carbon-to-nutrient ratios in forest soils. Soil Biol. Biochem. 81, 128-133 (2015).

109. Steinauer, K. et al. Plant diversity effects on soil microbial functions and enzymes are stronger than warming in a grassland experiment. Ecology 96, 99-112 (2015).

110. Su, X., Li, Y., Yang, B. \& Li, Q. Effect of plant diversity on soil microbial community in the subtropical forest soil (in Chinese with English abstract). Chin.J. Ecol. 37, 2254-2261 (2018).

111. Sun, C. Response of Rhizospheric Microbiology To Plant Competition and Moisture Stress (in Chinese with English abstract). Ph.D. dissertation, Northwest A \& F University (2017).

112. Sun, M. M. et al. In situ phytoremediation of PAH-contaminated soil by intercropping alfalfa (Medicago sativa L.) with tall fescue (Festuca arundinacea Schreb.) and associated soil microbial activity. J. Soils Sed. 11, 980-989 (2011). 
113. Sun, Y. M. et al. Influence of intercropping and intercropping plus rhizobial inoculation on microbial activity and community composition in rhizosphere of alfalfa (Medicago sativa L.) and Siberian wild rye (Elymus sibiricus L.). FEMS Microbiol. Ecol. 70, 218-226 (2009).

114. Tan, G. et al. Content and seasonal change of soil labile organic carbon under four different plantations in degraded red soil region (in Chinese with English abstract). Acta Agric. Univ. Jiangxi (Nat. Sci. Ed.) 36, 434-440 (2014).

115. Tang, X. Effects of Water and Nitrogen Coupling on Pasture Establishment in Hulunbuir (in Chinese with English abstract). Master's thesis, Chinese Academy of Agricultural Sciences (2018).

116. Tang, X. Y. et al. Increase in microbial biomass and phosphorus availability in the rhizosphere of intercropped cereal and legumes under field conditions. Soil Biol. Biochem. 75, 86-93 (2014).

117. Tang, X. Y. et al. Phosphorus availability and microbial community in the rhizosphere of intercropped cereal and legume along a P-fertilizer gradient. Plant Soil 407, 119-134 (2016).

118. Tang, Y., Xu, Y., Zheng, Y. \& Lei, B. Effects of wheat and faba bean intercropping on microorganism involved in nitrogen transformation in the rhizosphere soils (in Chinese with English abstract). J. Agric. Resour. Environ. 33, 482-490 (2016).

119. Thakur, M. P. \& Eisenhauer, N. Plant community composition determines the strength of top-down control in a soil food web motif. Sci. Rep. 5, 9134 (2015).

120. Tortorella, D. et al. Chemical and biological responses in a Mediterranean sandy clay loam soil under grain legume-barley intercropping. Agrochimica 57, 1-21 (2013).

121. van Eekeren, N. et al. A mixture of grass and clover combines the positive effects of both plant species on selected soil biota. Appl. Soil Ecol. 42, 254-263 (2009).

122. Vogel, A., Eisenhauer, N., Weigelt, A. \& Scherer-Lorenzen, M. Plant diversity does not buffer drought effects on early-stage litter mass loss rates and microbial properties. Glob. Change Biol. 19, 2795-2803 (2013).

123. Wagner, D., Eisenhauer, N. \& Cesarz, S. Plant species richness does not attenuate responses of soil microbial and nematode communities to a flood event. Soil Biol. Biochem. 89, 135-149 (2015).

124. Waldrop, M. P., Zak, D. R., Blackwood, C. B., Curtis, C. D. \& Tilman, D. Resource availability controls fungal diversity across a plant diversity gradient. Ecol. Lett. 9, 1127-1135 (2006).

125. Wang, D. The Research On The Interspecies Allelopathic Effect of Juglans Manchurian and Larix Gmelinii Forest Plantation (in Chinese with English abstract). Master's thesis, Northeast Forestry University (2014).

126. Wang, D. The Interspecific Competitive and Synergistic Effects in The Process Of Chromolaena Odorata Invasion (in Chinese with English abstract). Master's thesis, South China Agricultural University (2016).

127. Wang, H. et al. Mixed-species plantation with Pinus massoniana and Castanopsis hystrix accelerates $\mathrm{C}$ loss in recalcitrant coniferous litter but slows $\mathrm{C}$ loss in labile broadleaf litter in southern China. For. Ecol. Manag. 422, 207-213 (2018).

128. Wang, X., Ge, Y. \& Wang, J. Positive effects of plant diversity on soil microbial biomass and activity are associated with more root biomass production. J. Plant Interact. 12, 533-541 (2017).

129. Wardle, D. A., Bonner, K. I. \& Barker, G. M. Stability of ecosystem properties in response to above-ground functional group richness and composition. Oikos 89, 11-23 (2000).

130. Wardle, D. A. \& Nicholson, K. S. Synergistic effects of grassland plant species on soil microbial biomass and activity: Implications for ecosystem-level effects of enriched plant diversity. Funct. Ecol. 10, 410-416 (1996).

131. Wardle, D. A., Yeates, G. W., Williamson, W. \& Bonner, K. I. The response of a three trophic level soil food web to the identity and diversity of plant species and functional groups. Oikos 102, 45-56 (2003).

132. Wu, P. \& Xue, J. Effects of three different plantations on soil physicochemical and microbial characteristics in Krast region (in Chinese with English abstract). J. Nanjing For. Univ. (Nat. Sci. Ed.) 39, 67-72 (2015).

133. Xia, Z.-C., Kong, C.-H., Chen, L.-C., Wang, P. \& Wang, S.-L. A broadleaf species enhances an autotoxic conifers growth through belowground chemical interactions. Ecology 97, 2283-2292 (2016).

134. Yan, M. Effects of Different Cropping Patterns of Soybean and Maize Seedlings On Root Zone Soil Carbon and Nitrogen Mineralization (in Chinese with English abstract). Master's thesis, Northeast Agricultural University (2013).

135. Yuan, H. The Research on The Interspecies Effect of Fraxinus Mandshurica And Larix Gmelinii Forest Plantation (in Chinese with English abstract). Master's thesis, Northeast Forstry University (2015).

136. Zhang, J., Wang, S., Wang, Q. \& Liu, Y. Content and seasonal change in soil labile organic carbon under different forest covers (in Chinese with English abstract). Chin. J. Eco-Agric. 17, 41-47 (2009).

137. Zhang, S., Yu, M., Zhu, L. \& Qin, X. A study on microbial biomass C, N characteristics in different rehabilitating forests on degraded red soil (in Chinese with English abstract). Acta Agric. Univ. Jiangxi (Nat. Sci. Ed.) 32 101-107 (2010).

138. Zhao, J., Zeng, Z. X., He, X. Y., Chen, H. S. \& Wang, K. L. Effects of monoculture and mixed culture of grass and legume forage species on soil microbial community structure under different levels of nitrogen fertilization. Eur. J. Soil Biol. 68, 61-68 (2015).

139. Zhao, R. et al. Effects of plantation restoration approaches on soil enzyme activities and microbial properties in hilly red soil region (in Chinese with English abstract). Soils 44, 576-580 (2012).

140. Zhou, J. et al. Effect of Cunninghamia lanceolata-Betula luminifera mixed forests on soil microbial biomass and enzyme activity (in Chinese with English abstract). J. Northeast For. Univ. 43, 83-86 (2015)

141. Dassen, S. et al. Differential responses of soil bacteria, fungi, archaea and protists to plant species richness and plant functional group identity. Mol. Ecol. 26, 4085-4098 (2017).

142. Boer, W., Folman, L. B., Summerbell, R. C. \& Boddy, L. Living in a fungal world: impact of fungi on soil bacterial niche development. FEMS Microbiol. Rev. 29, 795-811 (2005).

143. Schimel, J. P. \& Hättenschwiler, S. Nitrogen transfer between decomposing leaves of different N status. Soil Biol. Biochem. 39, 1428-1436 (2007).

144. Gessner, M. O. et al. Diversity meets decomposition. Trends Ecol. Evol. 25, 372-380 (2010)

145. Mueller, K. E., Hobbie, S. E., Tilman, D. \& Reich, P. B. Effects of plant diversity, $\mathrm{N}$ fertilization, and elevated carbon dioxide on grassland soil $\mathrm{N}$ cycling in a long-term experiment. Glob. Change Biol. 19, 1249-1261 (2013).

146. Loreau, M. \& Hector, A. Partitioning selection and complementarity in biodiversity experiments. Nature 412, 72-76 (2001)

147. Nadrowski, K., Wirth, C. \& Scherer-Lorenzen, M. Is forest diversity driving ecosystem function and service? Curr. Opin. Environ. Sustain. 2, 75-79 (2010)

148. Kardol, P., Fanin, N. \& Wardle, D. A. Long-term effects of species loss on community properties across contrasting ecosystems. Nature 557, 710-713 (2018).

149. Moher, D., Liberati, A., Tetzlaff, J., Altman, D. G. \& The, P. G. Preferred reporting items for systematic reviews and meta-analyses: the PRISMA Statement. PLoS Med. 6, e1000097 (2009).

150. Anderson, J. P. E. \& Domsch, K. H. A physiological method for the quantitative measurement of microbial biomass in soils. Soil Biol. Biochem. 10 215-221 (1978)

151. Vance, E. D., Brookes, P. C. \& Jenkinson, D. S. An extraction method for measuring soil microbial biomass C. Soil Biol. Biochem. 19, 703-707 (1987).

152. Frostegard, A. \& Baath, E. The use of phospholipid fatty acid analysis to estimate bacterial and fungal biomass in soil. Biol. Fertil. Soils 22, 59-65 (1996).

153. Chen, H. Y. H. \& Brassard, B. W. Intrinsic and extrinsic controls of fine root life span. Crit. Rev. Plant Sci. 32, 151-161 (2013).

154. Fick, S. E. \& Hijmans, R. J. WorldClim 2: new 1-km spatial resolution climate surfaces for global land areas. Int. J. Climatol. 37, 4302-4315 (2017).

155. Zomer, R. J., Trabucco, A., Bossio, D. A. \& Verchot, L. V. Climate change mitigation: A spatial analysis of global land suitability for clean development mechanism afforestation and reforestation. Agric. Ecosyst. Environ. 126, 67-80 (2008).

156. Hedges, L. V., Gurevitch, J. \& Curtis, P. S. The meta-analysis of response ratios in experimental ecology. Ecology 80, 1150-1156 (1999).

157. Pittelkow, C. M. et al. Productivity limits and potentials of the principles of conservation agriculture. Nature 517, 365-368 (2015).

158. Bates, D., Mächler, M., Bolker, B. \& Walker, S. Fitting linear mixed-effects models using lme4. J. Stat. Softw. 67, 1-48 (2015).

159. Johnson, J. B. \& Omland, K. S. Model selection in ecology and evolution. Trends Ecol. Evol. 19, 101-108 (2004).

160. MuMIn: Multi-Model Inference. R package version 1.42 .1 (2018).

161. Cohen, J., Cohen, P., West, S. G. \& Aiken, L. S. Applied Multiple Regression/ correlation Analysis for The Behavioral Sciences (3rd ed.). (Routledge, London, 2003).

162. R Core Team. R: a language and environment for statistical computing. (R Foundation for Statistical Computing, 2018).

\section{Acknowledgements}

We thank Mr. Eric Searle for assisting with data analysis, and Dr. Markus Lange for providing his experimental data in The Jena Experiment and the funding agency, German Research Foundation (DFG). This study was funded by the Natural Sciences and Engineering Research Council of Canada (RGPIN-2014-04181, RTI-2017-00358, STPGP428641, and STPGP506284) and National Science Foundation of China for Distinguished Young Scholars (31625007).

\section{Author contributions}

C.C. and H.Y.H.C. designed research; C.C. and X.C. collected data; C.C., H.Y.H.C., and X.C. analysed data; C.C., H.Y.H.C., X.C., and Z.H. wrote the article. 


\section{Additional information}

Supplementary Information accompanies this paper at https://doi.org/10.1038/s41467019-09258-y.

Competing interests: The authors declare no competing interests.

Reprints and permission information is available online at http://npg.nature.com/ reprintsandpermissions/

Journal peer review information: Nature Communications thanks Monique Carnol and the other anonymous reviewers for their contribution to the peer review of this work. Peer reviewer reports are available.

Publisher's note: Springer Nature remains neutral with regard to jurisdictional claims in published maps and institutional affiliations. (c) Open Access This article is licensed under a Creative Commons Attribution 4.0 International License, which permits use, sharing, adaptation, distribution and reproduction in any medium or format, as long as you give appropriate credit to the original author(s) and the source, provide a link to the Creative Commons license, and indicate if changes were made. The images or other third party material in this article are included in the article's Creative Commons license, unless indicated otherwise in a credit line to the material. If material is not included in the article's Creative Commons license and your intended use is not permitted by statutory regulation or exceeds the permitted use, you will need to obtain permission directly from the copyright holder. To view a copy of this license, visit http://creativecommons.org/ licenses/by/4.0/

(C) The Author(s) 2019 